\title{
座談会
}

\section{日本の国際貢献からみた魅力的な人材とその育成 国際原子力機関(IAEA)での経験を軸に}

各国から，原子力分野の人材が集まる国際原子力機関 IAEA。その大きな役割の一つが, 各国の原子力の安全を向上させることだ。しかし，そのような国際舞台で活躍する日本人は, 多くない。その背景には語学力やコミュニケーション能力だけでなく，人材を送り出す企業 や役所などの組織の論理が，国際水準とずれていることがあるという。そこでは何が問題な のか。国際的な舞台での貢献が，ひいてはその人を送りだす組織や，あるいは日本そのもの の国益につながることを理解してもらうためには，何が必要か。国際機関で働く経験をもつ 4 人に，語ってもらった。

内閣府 原子力委員会委員 尾本 彰 (社)日本原子力産業協会 参与 小西俊雄 （独）原子力安全基盤機構 副理事長 中込良廣 文部科学省 核不拡散・保障措置室保障措置評価専門官 谷津祥一

聞き手＼cjkstart澤田哲生(本誌編集委員)

\section{はじめに}

澤田(聞き手) 本日は IAEA と関係の深い 4 人の方にお 集まりいただきました。最初に IAEA という国際機関で の人材, 特に日本からの寄与の現状などについてご意見 をいただきたく思います。まず2004年から IAEA の原子 力発電部長を 6 年間務められた尾本さんから。

尾本 IAEA で働く人にはレギュラースタッフ，コスト フリー・エキスパート，短期特別契約のエキスパート， それにインターンがいます。IAEA で働いている日本人 の割合は拠出金割合に比べておおむね 1 桁下ですし，コ ストフリー・エキスパートが多いのも特徴です。

一それは大きい問題ですね。

尾本 インターンには日本人が結構多いんです。IAEA でのインターン経験は，世界の中で日本の原子力がどう なっているのかを知るのに良い機会となります。私は， IAEA への日本人の貢献を議論するとき, IAEAの実務 はエクスターナル・エキスパート (external expert: EE) のお陰で成り立っている面を忘れてはならないと考えて います。基準づくり，ミッション，ワークショップなど においてIAEAを支えています。そのほかにも中込さ んのように, IAEA の活動の方向性についてアドバイス する方々もいます。

一エクスターナル・エキスパートとは外部の専門家で すか。

尾本そうです。IAEA 職員ではありません。例えば
IAEA は加盟国に専門家ミッションを送るとき，当該分 野の専門家を世界中から集めます。そういう専門家の情 報，つまりデータバンクがあるのです。そういう専門家 はIAEAのいわば宝です。日本人の貢献の議論をする とき，レギュラースタッフにやや焦点が合い過ぎだと思 います。

一EE は日本人の貢献が手薄なのですか。

尾本そうです。特にNuclear Energy 分野は弱い。 Safety はややあります。

\section{エクスターナル・エキスパートになるには ……鍵はロースター}

中込 個人でも手を上げれば $\mathrm{EE}$ のメンバーに入れてく

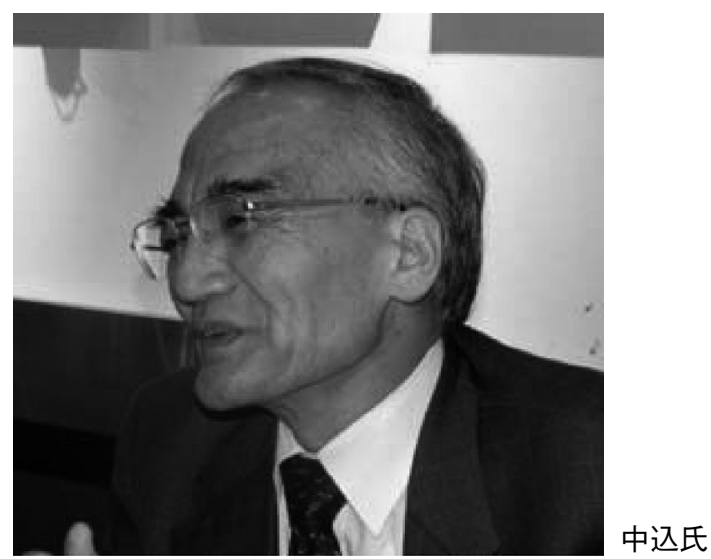


れるのですか？

尾本 Scientific secretary が集めます。ですから彼らに 情報が届いていることと, “顔が見えている”ことが重要 です。国の代表部に誰か専門家を送ってほしいと依頼す ることもありますが，来てほしい専門家を指名するケー スが多数あります。指名されるにはIAEA だけでなく 世界の専門家の間で知られて信頼されていないといけな いですね。

小西 IAEAのロースター (roster : 名簿, ここでは「専 門家としてIAEA の会合に来てもらえる候補者」の意) に，日本人が載るようにすることが大事です。顔が見え ないと呼んでもらえない。私が「職員増強」に力を入れて きたのは，その顔を見る人を内部に作りたいからです。 中込 小西さんがロースターの作成に関与したのですか ?

小西 尾本さんの要請で少しやりました。この分野はど こそこの誰々っていうのがわかればいい。日本人がロー スター作成者に情報と顔を慗ぐことができる人を，

IAEAに送り込まないといけない。私が邦人職員に期待 したい柱の一つです。

一で,どんな人がほしいのですか。

小西 日本での経験, 専門的なことを語れる人ですか ね。他国は日本を知りたいのです。それを伝えられる人，

ということで語学力は必須です。

一うーん。ちょっと深刻な感じですね。

尾本 ロースターに載る人は, 専門的知識が豊富でない とだめですね。また，ベストプラクティスをIAEA の 場を通じて流布させないといけないので，それをよく 知っている人。知識としてだけではなく, 実際その現場 にいた人がベターです。

\section{異文化を理解しコミュニケートする}

一それなら結構いませんか。保安院, JNES, 電力,

機構, メーカー, その他……

尾本 そう思います。ところがね, 英語のコミュニケー ション能力というとちょっと弱いのです。相手の考えを 理解し, 自分の意見をいう能力です。IAEA は多国籍の 場です。異文化を知って, 異文化への尊敬が必要だと思 います。

小西 相手の目線で考え, 相手の言葉で語ることが大事 だと思います。

尾本ひとつの言葉にしても, 文化的背景によって意味 する所が違うことがあります。そういうこともわかる人 がほしい。

一ハードルが高いですね。

中込 異文化相互理解の重要性はわかっているけど, い ざとなると日本人は視野狭さくになる。その点, IAEA はすごく分野が広い。

尾本 多様性を認めることですね。
中込 日本人は多文化環境の中で，落ちこぼれてしまい かねない。

小西 本来，アジアの仏教性がいきるところだと思うの ですがね。

谷津 私の見ていたところでは，そもそもコミュニケー ションしない人が日本人には結構いますね。コストフ リー・エキスパートなどには特にその傾向が強い。

中込 日本は人材を送り出す組織側にも問題があるので はないでしょうか。

\section{組織的なサポート体制を}

一ところでロースターへの自薦はできるのですか？

尾本 IAEA にはさまざまな分野のロースターがありま す。私も, 小西さんを通じて日本から貢献できる人のロー スターづくりをやろうとしましたが，うまくいかなかっ た。もちろん，小西さんのせいではありません。原産や 学会が，自信を持ってIAEA にロースター候補を出す ような仕組みがあるべきですよ。

中込 個人がいくら頑張っても, 組織的なサポートがな ければ，やはりダメだと思いますよ。その意味でもロー スター作成の “核”となる人物がいて，かつ組織的に支援 する体制が必要だと思います。

小西 結局, メーカーなどの各組織は本当の人材資源り ストを出すのを躊躇する。自分の本当の手の内 (人的資 源の実際) はあからさまにしたくないのでしょう。

一そうなんですか。

小西 私が働きかけた当時, アジア原子力安全ネット ワーク(Asian Nuclear Safety Network)の科学秘書 (Scientific secretary)を務めていた日本人職員から「こ んな専門家がほしい」という相談を受けました。某社に あたったら，「うちが判断，処理するので，情報と相手 方連絡先を教えてほしい」との答でした。不特定のニー ズに応えるためのロースターは不要だということです。

一うーん，それはイタいですねえ。

小西こんな経験を通じて, IAEAの活動に積極的に協 力するための基盤となる “専門家データベース”は作れな いと実感しました。これは経産省が号令をかけても本当 のものはできないと思います。逐次メンテナンスも大事 ですしね。私が採用情報をもっていますというリエゾン の連絡会ぐらいならできるかなと思っています。原産の 「国際人材協議会」のメンバーの方との個人的会話からの 着想です。要するに，実のある人材を抱えている組織の 理解とサポートがなければ，IAEAへの実質的な国際貢 献はできないってことです。

またロースターの維持管理の実質的な運用において, 人のつながり, つまりロコミの輪が予想以上に大きいと 思っています。IAEA でいえば, 職員間の口コミ, 会合 に参加した専門家 (EE)から Scientific Secretaryへの口 コミです。 
なお昨今は国際展開といって，メーカーが急に国際原 子力ビジネスに出ていこうとしていますが，IAEAの場 などでじっくり醉成された人間関係から国際関係の素地 ができていないと，長続きはしないと思いますよ。

一組織のバックアップがなければどうなるのでしょう か。

中込 人材のデータを教えることは，組織にとって損す ることになるのではなく，結果的に良い人材を出すこと で組織にとってもメリットが跳ね返ってくるのではない かと思うのですが。

尾本 一般論ですが，組織の長にお願いしてもなかなか 難しい。

背景にはIAEA に対する評価があると思います。間 違った想像かも知れませんが，産業界には「IAEA は途 上国支援中心の組織だから，人を出すことにメリットは ない」との見方が支配してきたと思います。

最近，フランス電力公社 $(\mathrm{EDF})$ の Inspector General の立場にある人が「EDF は世界一の原子力発電会社だけ れど広く世界から学ぶことがたくさんある」と明言して います。

小西 日本の貴重な人材を Scientific Secretaryに伝え るパスが極めて細い。だから，国内のある会合である人 が「行く気があるのに声がかからない」と不思議がってお られました。

一EE が少ないことが，ある意味すべてなのですね。 中込「私は日本の代表ではないと」言って逃げる人が多 い。聞き置くだけの人がいる。

\section{国際的な場で意見を表明し共有する能力}

一自分の意見を言わない限り，意志があるのかないの かわからない。つまり相手にしようがない。日本では， そういう自分の意見をキッチリ表明し説明できるような 能力を身につける教育や人材育成がされてないでしょ う。国際社会では自己主張をしなければ，存在さえ認め られないなかで, どうすればいいのですか。

小西 国際社会では，自分の意見をちゃんといえばリス ペクトされる。IAEA でこんな経験があります。私が担 当していた原子力海水淡水化が議題になった幹部会議に 出たことがある。二度目の会議には呼ばれなかった。「な ぜ?」と上司に尋ねたら「お前は自分の意見を言わない， 言わない人を会議に連れていく意味がない」とハッキリ 言われました。

一それでどうしました？

小西それ以降，長年の自分を改造し，「意見を言う」姿 勢に変えました。逆に何も言わなければ……存在しな いようなものだ」というわけです。

中込 役所からも大学院にたくさん来ています。しか し，“役人”という枠が邪魔をするのか，自分の言葉でな かなか意見を言わない。

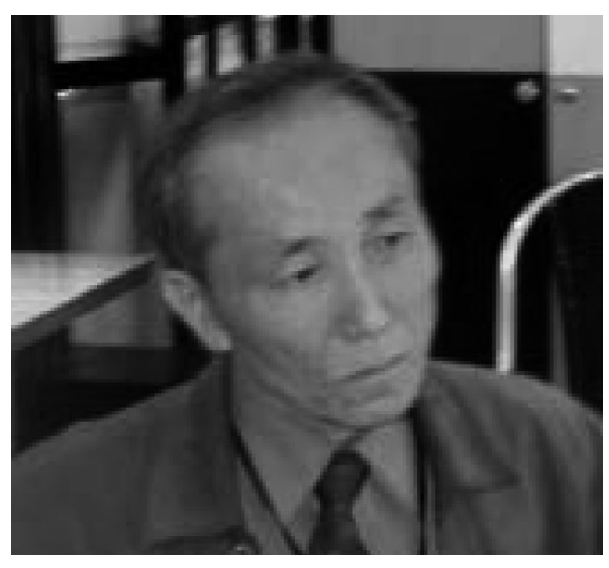

小西氏

尾本 その背景には，組織を離れて個人としての発言や 行動が控えめということがあります。組織の壁を超えた 活動や人材の流動性が低い。組織を超えて通用する知識 やスキルが身に付かないといけない。

中込やはり会社型社会なのかなあ。少しでも組織や体 制と違うこというといったりすると批判されることがあ る。

自由な発言の後のキャリアパスはどうなるのか 一出身組織という本籍を離れてどこまで自分の意見を 表明できるか……それが国際的に求められている。しか し，そのことが本籍にもどってから評価されないと脱力 しませんか。

小西 そういう例が多いですね。

谷津 いったん国際組織で働く身になれば，出元の組織 を離れてやることの重要性がよくわかるはずです。せっ かく国際的な舞台に上がったのですから，大いに声高に やるべきです。そこでの経験やそこから出てくる反省を 活かし, 取りまく状況を作って, 国際的に活かしていく。 そして，JPO(Junior Professional Officer)などを育てて いくとよいのではないでしょうか。

中込 例えば，ウイーンで 5 年間働いて州国したとす る。すると周りから,「 5 年間, ご苦労さんだけど良かっ たねえ？」となる。ウイーンは音楽の都，ワインも旨い 観光地だよねという思いが背景にある。羡望の目でみら

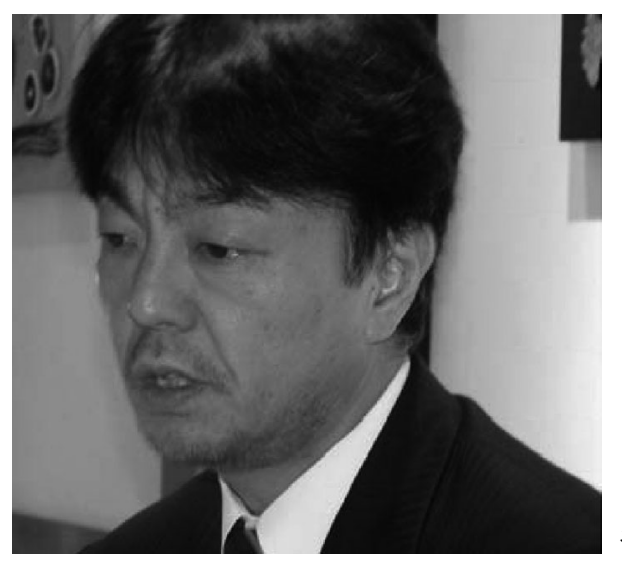

谷津氏 
れる。IAEA で查察のエキスパートになって戻って来た のに，畑違いの部署に配属されたりする。これではせっ かくの人材が活かせてなく，もったいないことになる。 谷津 IAEA はスペシャリストを求めています。一方, わが国の扮役所はジェネラリストを必要としている。 小西帰って来た人のキャリアパスの保証とまではいえ なくとも，人脈とおの扮のの専門分野で培ったノウハウ とデータベースのようなアセット (財産) として活用でき ないですかね。これは雲散霧消すべきものでなく利用し ましょうってことです。結果としてその人が活かされる 道の厚みを増すべきだと思います。

\section{学会や原産の役割}

中込 まさにこれからそれをやりましょう。学会や原産 に機会を設けて，各界をつないでね。

小西 人間, 情報, データベース……こういったものに 政策決定者がアクセスできる。そういう受け皿になる枠 組みと中身のデー夕が必要なのではないのかなと思いま す。実際にIAEA で研鑚し，IAEAを離れた人は最大 限活かされないとね。その意味で, 尾本さんのIAEA での経験や実績が, 東大の客員教授, 原子力委員という 新しいキャリアにつながったわけですから。良い事例と して大いに周知させたいですね。

\section{国際人材文化}

一さて, 多くの問題点が指摘されました。まず，組織 が人材そのもののみならず，人材情報を出したがらない のが非常に大きなバリアだということですね。

小西 短期的なメリット，つまりリターンが見えにくい のです。こういう人が欲しいとIAEA なりがいってく る。けれども，そんな有能な人は，うちだって長期間だ せますか，となる。

一では，いったい国際化とか国際性ってなんなのです か。国際○○と銘打った企画や人材育成がたくさんあり ますが。

谷津 人材○○とよく謳われ予算もついた。その結果， 国際舞台で働こうという若者も増えました。この背景に は，異文化理解もふくめて“国際人材文化”のようなもの が共有され䤑成されつつあると思うのです。ただ，なか なか出にくく, 再び䚻ってからどうなるかという不安や 事情はあまり変わっていない。

中込 良い人材を国際舞台に出して, ひと回り大きく育 て，さらに国際的に大きなビジネスにつなげていく….... という発想は欠如していると思うよ。

尾本 現場の管理職は近視眼になりがちですね。その一 方, もっと上層部の経営層は, 事情を知れば許容してく れるのでは。しかし，その上下の管理者相互での意思疎 通がどうもうまくいってないのかもしれない。こと国際 貢献に関しては。
一さて，ではこれから日本として業界としてどうすれ ばいいのか?

尾本 何をしたらいいのか 3 つ提案します。

(1) 出るのを許容する。世界舞台での活躍は長い目で 見れば組織にも利がある。投資として許容してもらう。

（2）日本が心地よくて離れたくない人が多いらしい。 一方，リスクを扔かして，武者修行に行ってこいと…... そういうことをフランスなどの大学院では卒業の条件と しているところもあります。

（3）それぞれの専門家が原子力を良くしたいと思え ば，世界から学ぶことはたくさんあります。世界から学 ぶ時に利用できる機関の例として IAEA があるという ことをもっと知ってもらう。

一居心地が良いっていうのは非常に厄介です。ハング リー精神やモティベーションがないのですね。

谷津 一番大きいのは給料ですよ……開発途上国でも, とりわけ貧しい国などと比較すればわかりやすいです。 自国の給料の何十倍ももらえるわけですから，モティ ベーションはおのずとあがります。

中込 まずね，意欲のあるひとが数人から始める。

小西 花を摘みに行くのではなく, 肥料をまくところか らやれと……他国はやっていると思うんです。

中込 評価すべきところはキッチリと評価されるような 仕組みも必要だね。

谷津 チャンスが，職を得る口があるのです。つまり， 活躍の場があることをまず知らしめるべしです。

\section{学会と産業界への期待と人材育成の課題}

\section{一どうやって知らせるのですか？}

谷津 鍵は情報共有と啓発活動です。そういう場を, 学 会を軸に産業界の協力を得てつくっていく。

小西学会と原産は今までも「国際人材」で一緒に取り組 んでいますが, 関係者の輪を広げてリンクを強めるべ しってことですかね。

中込 学会の大会で“国際環境”などというセッションを 設けるのも一つの方法です。

尾本 学会誌で興味をひくようなことを紹介して情報を 広める……IAEA はこんなことをしていますよ。こんな に面白いですよ。そういうページを設けて情報発信す る。

また人を送るためには，奨学金制度を充実すべきで す。産業界としても将来の海外展開を意識した奨学金制 度を設ける……投資が必要ですよ。

小西 学会はWEB など使ってもっとフレキシブルで双 方向の情報発信をやってほしい。まずは学会で国際人材 環境の HP をつくって情報発信すべきでしょう。

一役所の枠を超えた人材育成についてはどうでしょ う。

尾本 そういう実例を増やすことがまず重要です。ひと 


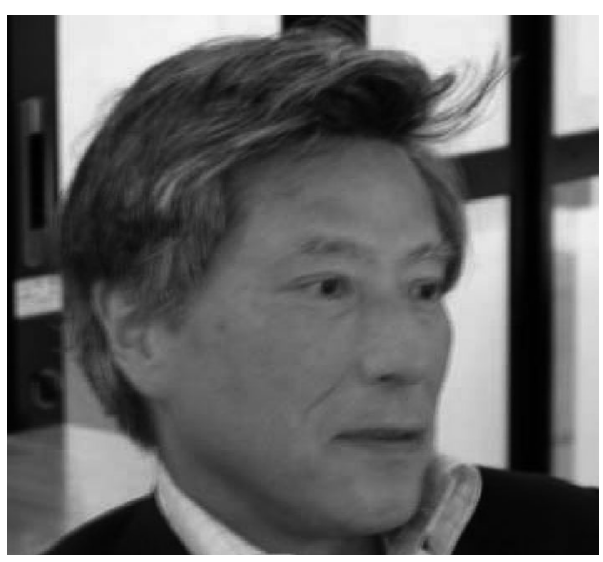

尾本氏

つの組織にとどまらない人が世の中の主役になるように なれば変わってくるんです。米国のように，発電運転経 験のある人が規制に回ってもよいのでは。それが日本の 原子力界のみならず，日本の国際的な足腰をより強くす ると思います。

中込 個々はもとより, 総体的な視点でやる必要があ る。総論的視点が欠けていれば, 個々のシステムは 100 点でも, 全体では50点くらいの評価になってしまうこと もある。それが国際社会の厳しさでしょう。

一コンポーネントは良いけれど総体としてシステマ ティックに連動して動いていない.........まのメーカー間 や役所間, 政治とも動きがちぐはぐな国際展開の現状と 共通しているような気がしますね。

\section{おわりに}

一最後に，それぞれにIAEAでの経験豊富な方々よ り，IAEA に関連して言い残したことは。

尾本 IAEAでは出身国を意識して働いてはいけませ ん。Conflict of interestという視点が大事です。個人が 世界の原子力の正しい発展に貢献していければよい。日 本人だからというものではない。ただ，出身国の事情や そこでの good practice や教訓には詳しいだろうという 期待は当然ありますので, それには答えていくべきで す。一方, IAEA は職員採用にあたって country profile を意識します。つまり IAEA における職員のバランス の良い分布ですね。

中込 出資額に比べて日本人員の数の比率は低くてもよ いのではないかな。

尾本 日本の看板背負っているわけではないのでね。

小西 日本人の忠義心からして, 送り出す側からは『行っ てこい。あとの面倒はちゃんとするから』といってもらっ た方が行きやすいんじゃあないかと思います。
一過保護じやあないですか。まあ，飢えてないから仕 方ないか。

小西 IAEAの発電と放射線利用それと Safeguards は 非常に重要ですよ。もっと日本から貢献した方がよい。 原子力の平和利用に徹する国として国際的に受け入れら れている日本は, 非核兵器国としてのベストプラクティ スもっているのですから。「貢献は布施」だと思わず，「親 切は人のためならず」の意を噛みしめたいですね。

谷津 私はIAEA に在職した頃から, 常々日本人を増 やすキャンペーンをしてほしい，また日本の各方面にも 協力して頂きたいと思ってきました。廊下の立ち話で議 論できるような人が必要なんですよ。日本人なんて目が 合わないように廊下の隅っこをうつむきかげんに歩いて たりする。情けないですよ。

一IAEA は日本人に対してもっとメッセージを発しろ ということですか。

谷津 そうです。一般の人にもかなり IAEA は浸透し て来ました。天野事務局長の誕生は絶好の機会ですね。 中込 IAEA 全体としては米国主導になっている。もっ と日本の考方方があって，それを出していっていいので はないかな。もう少し，日本の独自性をいれて発信すべ きだと思うな。

尾本 言葉を尽くさないと扔互いに理解できないのが世 界ですよね。

中込 異なる民族や文化も，同じ人間としてみるってこ とですよ……として異文化の人々ともっとコミュニケー ション能力を研鑚していくことが必要ですね。あのね, ボクたち，いちいち“I love you!”といわない傾向があ りますね……

小西 ええっ!? 私は言ってますょ(一同大笑)

国際的な場ではわかりきったこともハッキリいわないと ね。日本のような単一文化社会の“暗黙の了解”ではコ ミュニケーションできないと思いますよ。

一今日は大変良い話が聞けました。国際的にも国内的 にも様々なパートナーに理解と協力をお願いして, 国際 人材文化の醸成に乗り出すということですね。キーワー ドは異文化コミュニケーション。そのために，日本原子 力学会, 原子力産業協会が取りまとめる産業界, IAEA が互助体制を組んでいかなければならないということだ と思います。大学などでも異文化コミュニケーションの 演習など取り入れて, 多様な価值観を認める能力を身に つける必要がありそうですね。

大変ありがとうございました。

(2010年 4 月26日 都内ホテルにて取材) 